\title{
Impacts of the 2005 Caribbean bleaching event at Archipiélago de Los Roques National Park, Venezuela
}

\author{
E. Villamizar ${ }^{1,2}$, H. Camisotti² ${ }^{2}$ B. Rodríguez², J. Pérez ${ }^{1,2}$ \& M. Romero ${ }^{3}$ \\ 1. IZT, Universidad Central de Venezuela, estrellavillamizar@yahoo.com \\ 2. Fundación Científica Los Roques, fclr@cantv.net \\ 3. Postgrado Ciencias Biológicas, Universidad Simón Bolívar, elmarcuspe@hotmail.com
}

\author{
Received 13-VII-2007. C Corrected 20-XII-2007. Accepted 13-II-2008.
}

\begin{abstract}
Los Roques archipelago is the most important oceanic coral reef system of Venezuela. The bleaching condition of six coral reefs and patch reefs of the archipelago was monitored from August 2005 to March 2006. From two to six areas of $40 \mathrm{~m}^{2}$ were delimited at each reef at "shallow" (5-9 m) and "deep" (12-17 m) depths. The normal, pale, or bleached condition of all colonies was recorded. Three subcategories of pale or bleached were established as $<30 \%, 30-70 \%$ and $\geq 70 \%$. Surveys were done in August, October, and November 2005, and March 2006. The highest subsurface water temperatures were recorded with in situ data loggers (30 min sample rate) and occurred between October 7th and 8th, with a maximum temperature of $30.0^{\circ} \mathrm{C}$. Bleaching became evident the first week of November, in shallow and deep reef zones. A total of 19 corals and two hydrozoa species (Millepora alcicornis, Millepora complanata) were pale or bleached. Bleaching intensity was intermediate to low, yet statistically significant differences were found among the reef sites, but not between the two depth strata (Two-Factor ANOVA, $\mathrm{p}<0.05$ ). Coral communities that were most affected by bleaching had the highest coral cover $\left(76.25 \mathrm{col} / 40 \mathrm{~m}^{2}\right)$, and the colonies with the lowest proportion of dead tissue (average partial mortality $<6 \%$ ). Of the 1660 coral colonies monitored, $0.8 \%$ exhibited complete bleaching, $6.3 \%$ partial bleaching and 20.9\% were completely or partially pale. Diploria labyrinthiformis was partially pale or bleached at all sites. Not all species bleached at the same time. Palythoa caribaeorum, Millepora alcicornis, Millepora complanata, Diploria labyrinthiformis and Montastraea faveolata were the first species affected. Recovery from bleaching was nearly complete at the end of March; however, some colonies of $M$. faveolata recovered slowly, displaying pale areas longer than other species. Compared with bleaching at other Caribbean reefs in 2005, bleaching in Venezuela was less severe. Rev. Biol. Trop. 56 (Suppl. 1): 255-270. Epub 2008 May 30.
\end{abstract}

Keywords: 2005, bleaching, Los Roques, Southern Caribbean, coral reefs.

Bleaching is the loss of the symbiontic microalgae and/or their photosynthetic pigments in corals, which causes the corals to appear white (Coles \& Brown 2003). It can also occur in organisms other than corals. Bleaching of corals has been observed in the Caribbean since the early 1940s however most reports have been published since 1980, in conjunction with the repetitive ocurrence of mass bleaching events in the major Indo-Pacific and western Atlantic coral reef regions (Goreau 1964, Glynn 1984, Brown 1987, Williams \&
Bunkley-Williams 1990, Guzmán \& Cortés 1992, Glynn 1993, 1996, Podestá \& Glynn 2000, 2001). Since the first documented coral reef bleaching event in 1963, 63 severe to very severe ( $\geq 50 \%$ of corals bleached) events had been reported worlwide through 1990. From 1991 to 1998, 123 events were observed, 56 of which ocurred during the 1997/98 ENSO event (Glynn 2000). According to Hoegh-Guldberg (1999), events as severe as the 1998 event, the worst on record, are likely to become commonplace within 20 years. In addition, Donner et 
al. (2007) suggested that mass coral bleaching in the Eastern Caribbean may become a biannual event in 20-30 years based on modelling simulations.

In Venezuela very few studies have evaluated the extent of coral reef bleaching. Lang et al. (1992) reported a bleaching event of "low" intensity at Morrocoy National Park (northwestern continental coast of Venezuela) in 1987. Losada (1988) reported for the same period significant episodes of bleaching along the whole Venezuelan coast, from mid-November. Villamizar et al. (2003) evaluated the status of 13 coral reefs at Los Roques in October 1999 , reporting $<4 \%$ pale or partially bleached coral colonies and none totally bleached.

The coral reefs at Archipiélago de Los Roques National Park comprise the most important coral reef system in Venezuela (Villamizar 2003, Weil 2003), and are considered among the most developed, diverse, and healthy reef systems in the Caribbean region (Kramer 2003). The entire park has an area of 2,251 $\mathrm{km}^{2}$ (including the surrounding waters), while the area of the keys is only $40.61 \mathrm{~km}^{2}$. It is composed of two long reefs, the southern (24 km long), and eastern (32 km long) barrier reefs, 42 keys, and hundreds of patch reefs (Rodriguez 2001). Due to its geographic location, the archipelago is outside the area routinely influenced by hurricanes. The only populated center is on Gran Roque Key (at the northeast of the park) with approximately two thousand people; therefore land-based anthropogenic impacts are assumed to be minimal. For these reasons, Los Roques's reefs provide a valuable comparison to other more degraded reefs in Venezuela and the Caribbean.

Given the increasing frequency of coral bleaching events in the last two decades (Glynn 2000) and the catastrophic impacts caused recently in most of the Caribbean reefs (HoeghGuldberg 1999), we considered it a high priority to initiate an annual bleaching monitoring program on this important coral reef system. Moreover, 2005 was predicted as an unusually warm year (NOAA's Coral Reef Watch Satellite Bleaching Alert System), and therefore it was important to evaluate the ecological consequences for Caribbean coral reefs. Considering all these points, in 2005, an annual monitoring program for bleaching in Los Roques's coral reefs was initiated.

The main goal of this study was to evaluate the impact of the 2005 Caribbean bleaching event in Los Roques, and compare the intensity of bleaching among some of the most representative coral areas and types of coral communities of the archipelago: reefs from the eastern barrier (BM: Boca del Medio), southern barrier (BC: Boca de Cote and CS: Cayo Sal), southwestern fringing reefs (DMS: Dos Mosquises Sur and DMH: Dos Mosquises Herradura), and patch reefs (CA: Cayo de Agua). According to the predictions for the Caribbean (NOAA, 2005), we expected a bleaching event of high intensity with higher impacts from bleaching in the shallower zones of the reefs and in the patch reefs, compared to deeper zones and extensive fringing reefs.

\section{MATERIALS AND METHODS}

Six representative coral reef communities from Los Roques were strategically selected to monitor the impact of the 2005 bleaching event (Table 1). Of the six reef monitoring sites, BC, CS, and DMS have well developed reefs, extending to an average depth of $30 \mathrm{~m}$; $\mathrm{BM}$ is a narrow reef, with a maximum depth of $12 \mathrm{~m}$; DMH is a very shallow fringing reef, shaped as a horseshoe; and CA is a patch reef, with groups of corals intermixed with sandy patches. The latter two are at an average depth of $2.5 \mathrm{~m}$.

Surveys were conducted at each site from August 2005 to March 2006 on the following dates: July 30 to August 10, October 1 to 9, October 29 to November 2, 2005 and March 18 to April 1, 2006.

Four to six $40 \mathrm{~m}^{2}$ belt transects $(10 \mathrm{~m}$ length $\mathrm{x} 4 \mathrm{~m}$ wide) were randomly established along the selected depth range at each reef; half of them at the "shallow" (5-9 m) and the other half at the "deep" strata (12-17 m), except Cayo de Agua, where due to the limited number of 
TABLE 1

Site information and area sampled, at each of the studied reefs, Archipiélago de Los Roques National Park

$\begin{array}{lcc}\text { Reef } & \begin{array}{c}\text { Site } \\ \text { code }\end{array} & \text { Reef type } \\ \text { Boca del Medio } & \text { BM } & \text { Barrier (East) } \\ \text { Boca de Cote } & \text { BC } & \text { Barrier (SE) } \\ \text { Cayo Sal } & \text { CS } & \text { Barrier (SW) } \\ \text { Dos Mosquises Sur } & \text { DMS } & \text { Fringing (SW) } \\ \text { Dos Mosquises Herradura } & \text { DMH } & \text { Fringing (SW) } \\ \text { Cayo de Agua } & \text { CA } & \text { Patches (SW) }\end{array}$

live coral colonies, only two belt transects were established, both at $3.0 \mathrm{~m}$ deep. In the case of the fringing reef of $\mathrm{DMH}$, all corals were between $0.5 \mathrm{~m}$ and $4 \mathrm{~m}$ deep (only shallow waters), and because of their shape and position in relation to currents, two different subareas or fringes of this reef were monitored: the front reef (DMHFR) and the back reef (DMHBR). The belt transects were delimited with nylon, attached to steel bars in the plot corners. The number of coral species, and the number, size and health condition of the coral colonies, were recorded. Also zoanthids and fire coral colonies were monitored. The parameters to assess the health condition of the colonies were: partial mortality, diseases and overgrowth. The percentage of total partial mortality in a colony is calculated as the sum of the two types of mortality, recent mortality and old mortality, both estimated as the tridimensional (3-D view) total surface area of colony. Old mortality is recognized and differentiated from recent mortality because the corallite structures are either gone or covered over by organisms that are not easily removed. Six different types of coral diseases were considered: yellow blotch disease (YBD), black band disease (BBD), red band disease (RBD), white band disease (WBD), white plague (WP), and dark spot disease (DSD). Also, coral overgrowth by algae or other invertebrates were considered. The colonies that could not be matched with one of these disease categories were placed into the category "not identified (NI)". Bleaching was assessed by classifying coral colonies according to their color pattern. Color categories were defined as normal, pale, or bleached. The colonies were categorized as "normal" if they did not show any loss of the characteristic color specific to the species; as "pale" if loss of color intensity was evident, but some color was retained, and "bleached" only when a portion (partially bleached) or all (totally bleached) of the coral surface tissue was completely white but with live polyps. In the cases of pale or bleached colonies, the percentage of total affected coral cover (3-D) was estimated for each colony.

Subsurface water temperatures were monitored with five Hobotemp data recorders (Onset, Model UA001-08), at different reef sites of the archipelago every 30 minutes. Three were placed at bleaching study areas (BM, CS, DMS), and the remaining two were placed at the southeast tip of the archipelago (SEB: Sebastopol) and at Laguna Central (LC), as representative sites for strong currents and shallow reef areas (Villamizar et al., 2003), respectively (Fig. 1). The loggers were fixed to the bottom near the coral, at an average depth of $8 \mathrm{~m}$, and data was registered from August 2005 to end of March 2006. For the purpose of this study, subsurface water temperatures above $29.5^{\circ}$ were considered as warm waters, since from all the data registered during 2005 and 2006, in three of the studied reefs, it was the highest average of subsurface monthly 


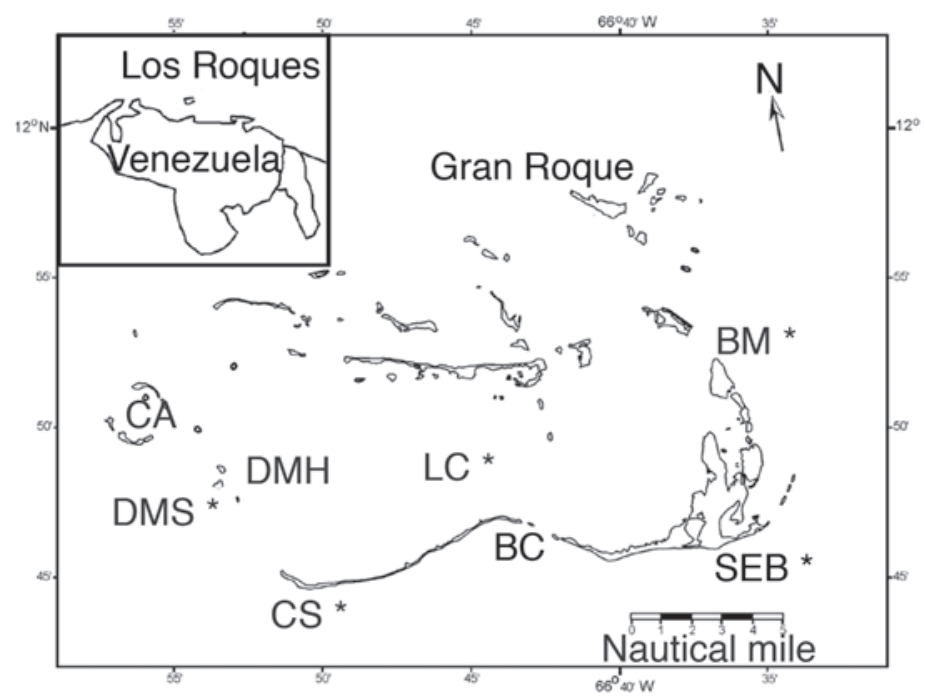

Fig. 1. Archipiélago de Los Roques National Park, Venezuela, showing the studied reef sites (DMS, DMH, CA, CS, BC, $\mathrm{BM}$ ) and the localities with temperature data loggers (DMS, CS, SEB, BM, LC ) . Abbreviations of reef sites in Table 1; “*”: Hobo sites.

temperature estimated (authors, unpub. data). The Degree Heating Weeks index (DHW) was recorded for each study site, as a measure of thermal stress for corals. According to NOAA (2005), each DHW represents one week of temperatures $1^{\circ} \mathrm{C}$ above the maximum highest monthly average.

\section{Data Analysis}

In relation to the coral community structure, the density of coral colonies was estimated, and the most abundant species (dominant species) were identified at each reef site. Dominant species were defined as coral species that comprise more than ten percent of the coral community at each site. The bleaching condition of coral colonies within the belt transects was assessed along the four survey dates, and the number of colonies and affected surface area of each coral was estimated. The average percentage of normal, pale and bleached colonies at each reef was estimated. The intensity of paling or bleaching is defined in this paper as the amount of tissue (\%) on a colony affected by paling or bleaching. Three range categories of paling and bleaching were established: < 30\%, 30 - 70\%, $>70 \%$. The prevalence of bleaching was calculated for each site and each species by dividing the number of affected colonies of each coral species by the total number of colonies of that species at each site. Bleaching prevalence data were normalized by calculating the arcsine of the square root (Zar 1999), and homogeneity of variance was tested with the Levene Test, prior to applying the parametric analysis. A two-factor Analysis of Variance was used to test the significance of the differences between mean bleaching levels among reef localities and depth strata. For this analysis, only the reefs with plots at the two depth strata were considered (BC, CS, DMS, BM). Significant differences between means were tested with a Duncan Test post-hoc comparison. A Chisquare $\left(\mathrm{X}^{2}\right)$ Test was used to compare paling and/or bleaching intensity categories among species for the most affected species, that is, with the highest bleaching prevalence or bleaching intensity (A. agaricites, A. lamarcki, D. labyrinthiformis, $M$. annularis, $M$. faveolata, and P. astreoides) for the six localities studied. In this analysis the total number of colonies 
with particular bleached or pale categories was counted. All statistical analyses were run using SPSS v.12 program.

\section{RESULTS}

\section{Reef Sites and Condition of Coral Community}

Table 2 shows measured parameters of the coral community and condition of coral colonies, for the studied reef sites. The reefs from the southern barrier reef (BC and CS) and DMS had a higher number of species and density of coral colonies than the other reef sites (BM, DMH, CA). However, the average diameter and height of coral colonies (and their respective standard deviations) of these communities are aproximately similar but CA, where Acropora palmata is the dominate species with colonies of medium and large sizes. Estimations of the percentage of colony partial mortality indicated a high variability among colonies in the proportion of their dead tissues. Colonies from BC reef had the lowest average of dead tissue (5.85\%), and the colonies from BM reef, have the highest average (30.74\%). Considering the six reef sites studied, few colonies $(n=126)$ of the total monitored $(n=1660)$ were affected by diseases, the most common being Yellow Blotch Disease and Dark Spot Disease.

The relative dominance of coral species varied between sites. Montastraea annularis (Ellis \& Solander 1786) (24.7\%) and Porites astreoides Lamarck, 1816 (11.8\%) were the most important species in BM reef; Agaricia agaricites (Linnaeus, 1758) (20.3\%), P. astreoides (16.1\%) and Montastraea faveolata (Ellis \& Solander, 1786) (10\%) in BC; Montastraea cavernosa (Linnaeus, 1766) (22.8\%) and Siderastrea siderea (Ellis \& Solander, 1786) (10.1\%) in CS; M. annularis (16.5\%), M. cavernosa (13.7\%), Colpophyllia natans (Houttuyn, 1772) (13.7\%), and P. astreoides (11.8\%) in DMS; P. astreoides (29.1), Acropora cervicornis (Lamarck, 1816) (16.2\%), and Diploria strigosa (Dana, 1846) (14.6\%) in DMH; A. palmata (Lamarck 1816) (67\%), P. astreoides (13.8\%) and D. strigosa (10\%) in CA.

TALBE 2

Number of coral species, density of coral colonies, and colony health condition at each of the studied reefs, Archipielago de Los Roques National Park

\begin{tabular}{|c|c|c|c|c|c|c|}
\hline $\begin{array}{l}\text { Reef } \\
\text { site }\end{array}$ & $\begin{array}{l}\text { Number } \\
\text { of Species }\end{array}$ & $\begin{array}{c}\text { Average } \\
\text { density } \\
\left(\text { col. } / 40 \mathrm{~m}^{2}\right)\end{array}$ & $\begin{array}{l}\text { Avg. colony } \\
\text { diameter } \\
( \pm \mathrm{SD})(\mathrm{cm})\end{array}$ & $\begin{array}{l}\text { Avg. colony } \\
\text { height } \\
( \pm \text { SD) }(\mathrm{cm})\end{array}$ & $\begin{array}{l}\text { Avg. Partial } \\
\text { Colony mortality } \\
(\%)( \pm \mathrm{SD})\end{array}$ & $\begin{array}{l}\text { Number of colonies } \\
\text { with disease }\end{array}$ \\
\hline BM & 20 & 42.50 & $55.68(67.49)$ & 36.42 (44.49) & $30.74(34.75)$ & $\begin{array}{c}11 \text { DSD, } 1 \text { WBD, } 5 \\
\text { YBD }\end{array}$ \\
\hline $\mathrm{BC}$ & 28 & 76.25 & $41.62(56.32)$ & 28.67 (49.75) & $5.85(14.02)$ & $\begin{array}{l}10 \text { DSD, } 2 \text { WBD, } \\
\text { 1WP, } 5 \text { YBD }\end{array}$ \\
\hline CS & 26 & 72.16 & 40.54 (33.65) & $30.04(26.42)$ & 16.41 (26.09) & $\begin{array}{c}1 \mathrm{BBD}, 4 \mathrm{DSD}, \\
1 \mathrm{WBD}, 8 \mathrm{YBD}, 6 \mathrm{NI}\end{array}$ \\
\hline DMS & 30 & 75.66 & 50.79 (58.95) & 35.52 (48.96) & $15.70(23.85)$ & $\begin{array}{c}8 \mathrm{DSD}, 19 \mathrm{NI}, 1 \mathrm{WBD}, \\
4 \mathrm{WP}, 8 \text { YBD }\end{array}$ \\
\hline DMH & 14 & 30.87 & 53.74 (61.73) & 28.8 ( 22.13) & 25.45 (31.03) & $\begin{array}{c}1 \mathrm{BBD}, 1 \mathrm{DSD}, 2 \mathrm{NI}, \\
1 \mathrm{RBD}, 2 \mathrm{WBD}, 3 \mathrm{YBD}\end{array}$ \\
\hline CA & 11 & 45.00 & 83.54 (26.93) & 57.98 (12.73) & $22.55(31.26)$ & $\begin{array}{l}12 \text { NI, } 4 \text { WBD, } \\
1 \text { WP, } 5 \text { YBD }\end{array}$ \\
\hline
\end{tabular}

BBD: Black Band Disease, DSD: Dark Spot Disease, RBD: Red Band Disease, YBD: Yellow Blotch or Band Disease WP: White Plague, NI: Not Identified. 


\section{Water Temperature}

Fig. 2 shows the variations of seawater temperature during the study period. All the reef sites showed similar tendencies, with an increase in temperature from August to midOctober, decreasing progressively until April of the following year. The highest water temperatures were registered the first week of October. All the sites registered approximately the same maximum temperature $\left(29.4-29.92^{\circ} \mathrm{C}\right)$, except LC site, registering the highest value of $30.8^{\circ} \mathrm{C}$. For all reef sites the highest temperature was reached between October 7th and 8th (Fig. 2). The Degree Heating Weeks (DHW) in the reefs was variable, depending on the locality. The maximum DHW (aprox.12) was found in the patch reef of Laguna Central (2-5 m deep), while the minimum DHW (approx. 2) was found in SEB (southern barrier) and BM (eastern barrier). Intermediate DHW values (5) were measured in DMS reef and CS (at the southwest of the archipelago). Temperature decreased from August 8 to 25, at all localities except LC, reaching a value of $27.46^{\circ} \mathrm{C}$.

\section{Temporal and Spatial bleaching pattern}

At all sites, bleaching intensity increased progressively from August to November 2005. Fig. 3 shows the average of pale (A) and bleached (B) coral surface at the four survey dates for the reef sites and depths. The highest percentage of pale coral surface (Fig. 3A) was estimated for BCS (Boca Cote Shallow) in November 2005. Likewise, with the exception of this reef site, the pale condition of colonies remained at approximately the same value during October and November, with a slight increase in March 2006. For all the dates, the intensity of bleaching was low, under $8 \%$ for all the reefs (Fig. 3B). Coral colonies from DMS and BCS had the highest intensity of bleaching; however, their recovery was almost complete by March 2006. In general, coral tissue bleaching recovery was nearly complete at the end of March; however some colonies of M. faveolata had irregular small pale spots.

The other variable indicating of the severity of bleaching was the total number of coral colonies affected. At all sites, the colonies that

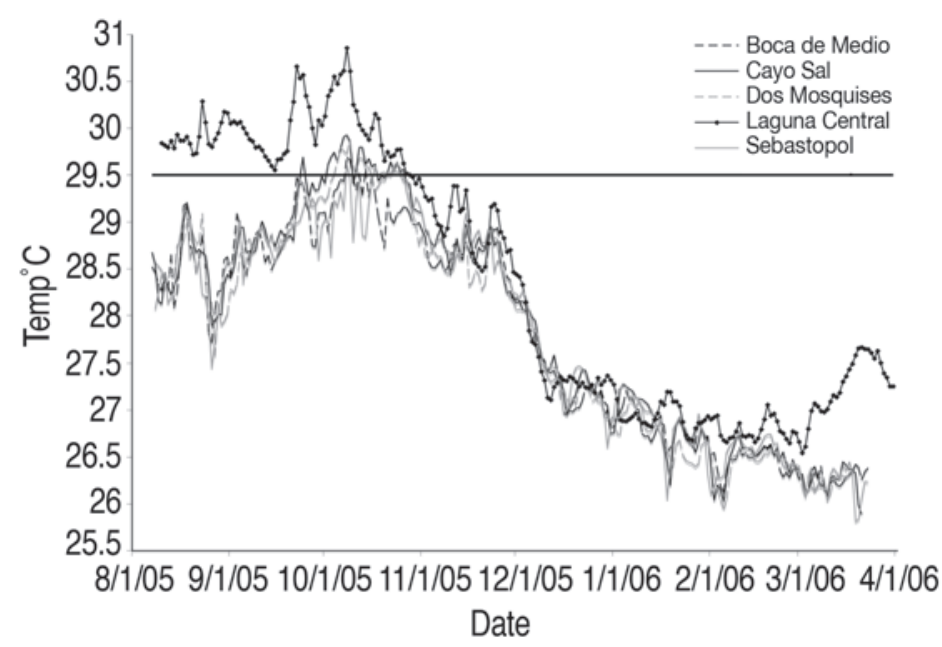

Fig. 2. Daily average temperature records every $30 \mathrm{~min}$ at the reef bottom (average depth $=8 \mathrm{~m}$ except Laguna Central $=2$ m) at five reefs at Archipiélago de Los Roques National Park, from August 2005 to March 2006. Three monitored reef sites (BC, CS, DMS) and two reference sites (SEB: Sebastopol and LC: Laguna Central) are included. The transverse line is a visual reference to indicate water over $29.5^{\circ} \mathrm{C}$ (“warm waters”). 

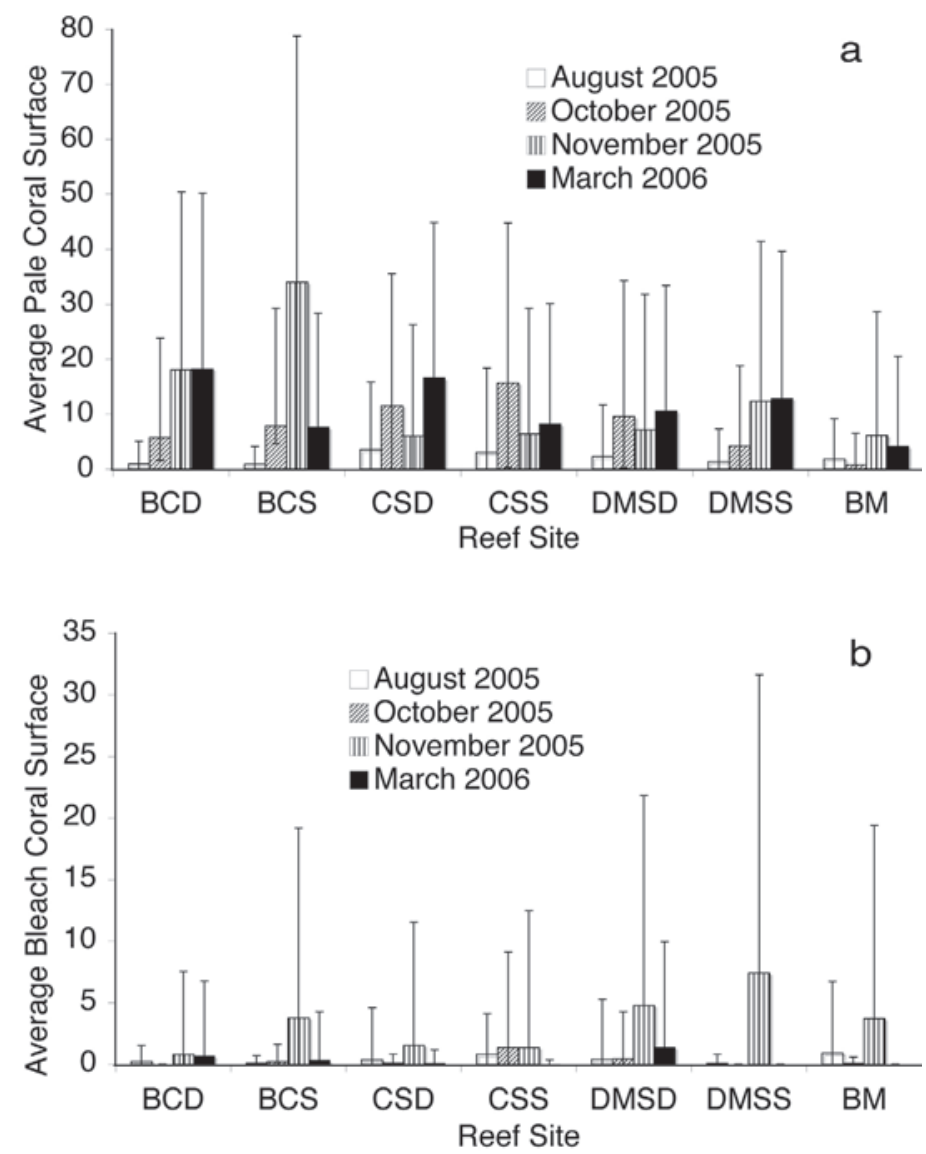

Fig. 3. Evolution of average intensity of paling (A) and bleaching (B) by colony over the period of study. Only the sites monitored in the four survey dates are included. BCD: Boca de Cote Deep, BCS: Boca Cote Shallow, CSD: Cayo Sal Deep, CSS: Cayo Sal Shallow, DMSD: Dos Mosquises Sur Deep, DMSS: Dos Mosquises Sur Shallow, BM: Boca del Medio. Error bars represent standard deviations.

were pale the first week of October, bleached partially or totally during the first week of November. However, a very low number of colonies of the total monitored $(\mathrm{N}=1660)$ were completely bleached (0.80\%); a higher number were partially bleached (6.26\%) and a higher proportion were completely or partially paled (20.94\%).

Not all the species bleached at the same time. Of all the studied reefs, Palythoa caribaeorum (Duchassaing \& Michelotti, 1860), Millepora alcicornis (Linnaeus, 1758) Millepora complanata (Lamarck, 1816), Diploria labyrinthiformis (Linnaeus, 1758) and
M. faveolata were the species affected first. Table 4 shows the proportion of colonies with pale and bleached condition for each reef site, during the third survey. For all the sites, the proportion of colonies totally or partially paled was higher than the proportion of colonies total or partially bleached. This difference is particularly conspicuous for BC reef (\% paled = 35.74 , \% bleached $=7.87$ ). In general, the percentage of colonies bleached (total or partially) was lower than $10 \%$.

There were significant differences in the percentage of pale or bleached colony surface among sites; however, there was not a signifi- 
TABLE 3

Total number of surveyed colonies by species and localities

\begin{tabular}{|c|c|c|c|c|}
\hline Species & $\mathrm{BC}$ & $\mathrm{BM}$ & CS & DMS \\
\hline A. agaricites & 62 & 17 & 19 & 18 \\
\hline A. lamarcki & 7 & 1 & 5 & 22 \\
\hline A. tenuifolia & 0 & 0 & 0 & 1 \\
\hline C. natans & 10 & 3 & 18 & 58 \\
\hline D. cylindrus & 1 & 0 & 2 & 0 \\
\hline D. labyrinthiformis & 23 & 9 & 40 & 9 \\
\hline D. strigosa & 10 & 2 & 39 & 5 \\
\hline E. fastigiata & 6 & 1 & 1 & 6 \\
\hline L. cucullata & 7 & 1 & 0 & 1 \\
\hline M. alcicornis & 4 & 6 & 13 & 5 \\
\hline M. annularis & 17 & 42 & 35 & 70 \\
\hline M. cavernosa & 27 & 6 & 99 & 58 \\
\hline M. complanata & 1 & 7 & 4 & 1 \\
\hline M. faveolata & 30 & 15 & 27 & 22 \\
\hline M. franksi & 8 & 3 & 9 & 14 \\
\hline M. meandrites & 11 & 0 & 10 & 12 \\
\hline P. astreoides & 49 & 20 & 38 & 50 \\
\hline P. branneri & 0 & 0 & 1 & 0 \\
\hline S. intersepta & 3 & 8 & 10 & 16 \\
\hline S. siderea & 5 & 17 & 44 & 11 \\
\hline
\end{tabular}

cant effect of depth, and no depth $\mathrm{X}$ site interaction (Table 5).

\section{Species specific responses to bleaching}

A coral species bleaching analysis, for the period of maximum extent of bleaching (third sampling), is shown in Figs. 4 and 5. A total of 19 corals and two hydrozoa species (M. alcicornis, M. complanata) were pale or bleached. The figures show the prevalence of paling or bleaching (\%) of each coral species as the sum of the three intensity categories for each reef site. There was high variability in the intensity of paling or bleaching for each species among the reef sites. BC was the reef where more species had pale or bleached condition. Most species showed paling rather than bleaching, and most of each particular species presented higher pale prevalence than bleached prevalence. D. labyrinthiformis was the single species with pale condition at all studied reefs, however the proportion of pale colonies was notably higher in $\mathrm{BC}$ compared with the other three reefs (Fig. 4). In the case of E. fastigiata, the high prevalence of pale condition for CS was because the only colony of this species found in the area was pale (Fig. 4, Table 3).

In general, few species showed partial bleaching, and usually lower than 50\% (Fig. 5).

TABLE 4

Relative percentage of pale or bleached colonies at the studied reef sites, during the height of the bleaching event (November 2005)

$\begin{array}{lccc}\text { Reef site } & \text { Total Coral Heads } & \begin{array}{c}\text { \% Total or Partially Pale } \\ \text { Colonies }\end{array} & \text { \% Total or Partially Bleached Colonies } \\ \text { BM } & 170 & 10.00 & 7.65 \\ \text { BC } & 305 & 35.74 & 7.87 \\ \text { CS } & 434 & 8.99 & 3.46 \\ \text { DMS } & 424 & 15.33 & 9.91 \\ \text { DMH } & 247 & 8.91 & 3.24 \\ \text { CA } & 80 & 10.00 & 7.50\end{array}$


TABLE 5

Summary results for a Two-Factor ANOVA on bleaching intensity with factors site, depth, and depth $X$ location interaction

$\begin{array}{lcccccc}\text { Effect } & \text { DF } & \text { MS Effect } & \text { DF } & \text { MS Error } & \text { F } & \text { p-level } \\ \text { Reef } & 3 & 1.889 .898 & 288 & .185893 & 10.16662 & \mathbf{. 0 0 0 0 0 2} \\ \text { Depth } & 1 & .046617 & 288 & .185893 & .25077 & .616913 \\ \text { Interaction } & 3 & .026639 & 288 & .185893 & .14331 & .933906\end{array}$

Significant differences in bold $(\mathrm{p}<0.05)$.

Only six species had an intensity of bleaching in the second category (30 - 70\%), and seven in the third category $(\geq 70)$. These species were: M. alcicornis, A. agaricites, Agaricia lamarcki Milne Edwards \& Haime, 1851, P. astreoides, $M$. meandrites, $M$. faveolata, and D. labyrinthiformis. Also many colonies of M. alcicornis and $M$. annularis were partially bleached at all localities. The bleaching intensity of $M$. alcicornis was always $>70 \%$. Leptoseris cucullata (Ellis \& Solander, 1786), though infrequently encountered (only nine colonies and only in BC), had a partial bleaching prevalence of $100 \%$ (in the first and second bleaching intensity category) during the maximum period of bleaching.

Categories of bleaching intensity among species were statistically significant $\left(\chi^{2}=21.03\right.$, 12df, $\mathrm{p}<0.05)$. Table 6 shows the residuals of this test, pointing out for some species, a number of colonies higher than expected in some categories and a lower number in others. For example, for the highest category of bleaching, the proportion of $M$. faveolata, $P$. astreoides and $C$. natans was greater than the expected according to the null hypothesis (positive residuals). Most colonies of A. lamarcki, $D$. labyrinthiformis and $M$. annularis, had a greater than expected intermediate level of affected tissue (30 - <70\%), and most A. agaricites colonies were affected at a low level of bleaching or pale intensity $(<30 \%)$.
TABLE 6

Residuals Analysis ( $X^{2}$ test) for the different categories of pale or bleached condition for the most affected species in Los Roques, during the height of the bleaching event (November 2005)

$\begin{array}{lrrr}\text { Especies } & <30 & 30-70 & >70 \\ \text { A. agaricites } & \mathbf{2 0 . 5 1 6} & -9.226 & -11.290 \\ \text { A. lamarcki } & -7.581 & \mathbf{1 1 . 1 2 9} & -3.548 \\ \text { D. labyrinthiformis } & -1.790 & \mathbf{3 . 5 6 5} & -1.774 \\ \text { M. annularis } & 1.016 & \mathbf{3 . 2 7 4} & -4.290 \\ \text { M. faveolata } & -2.661 & -2.242 & \mathbf{4 . 9 0 3} \\ \text { P. astreoides } & -5.210 & -3.565 & \mathbf{8 . 7 7 4} \\ \text { C. natans } & -4.290 & -2.935 & \mathbf{7 . 2 2 6}\end{array}$

Values in bold were significant $(\mathrm{p}<0.05)$.

\section{DISCUSSION}

\section{Temporal and Spatial pattern of bleaching}

The results of this study showed the evolution of a low intensity coral bleaching event at Los Roques during 2005. It was characterized by a high temporal synchrony of bleaching for all the reef sites considered. The event began gradually in October 2005, with maximum paling and bleaching in November, and almost complete recovery by the end of March 2006. According to these results, four phases of the 


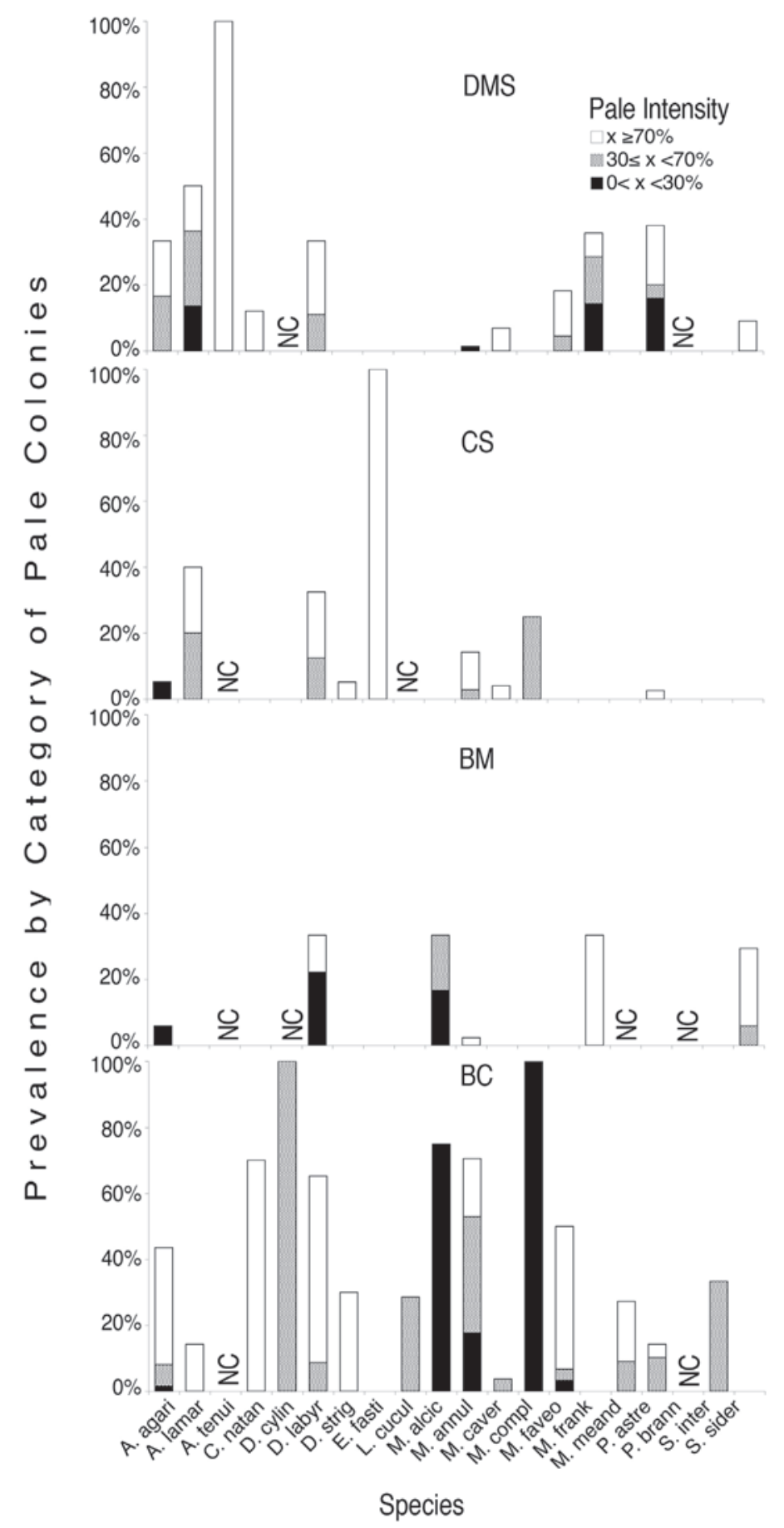

Fig. 4. Prevalence of pale by species in three categories of intensity $(0<X<30 \%, 30-70 \%$, $>70 \%$.) during the period of maximum bleaching (November). The total of colonies at each locality are indicated in Table 3 . 


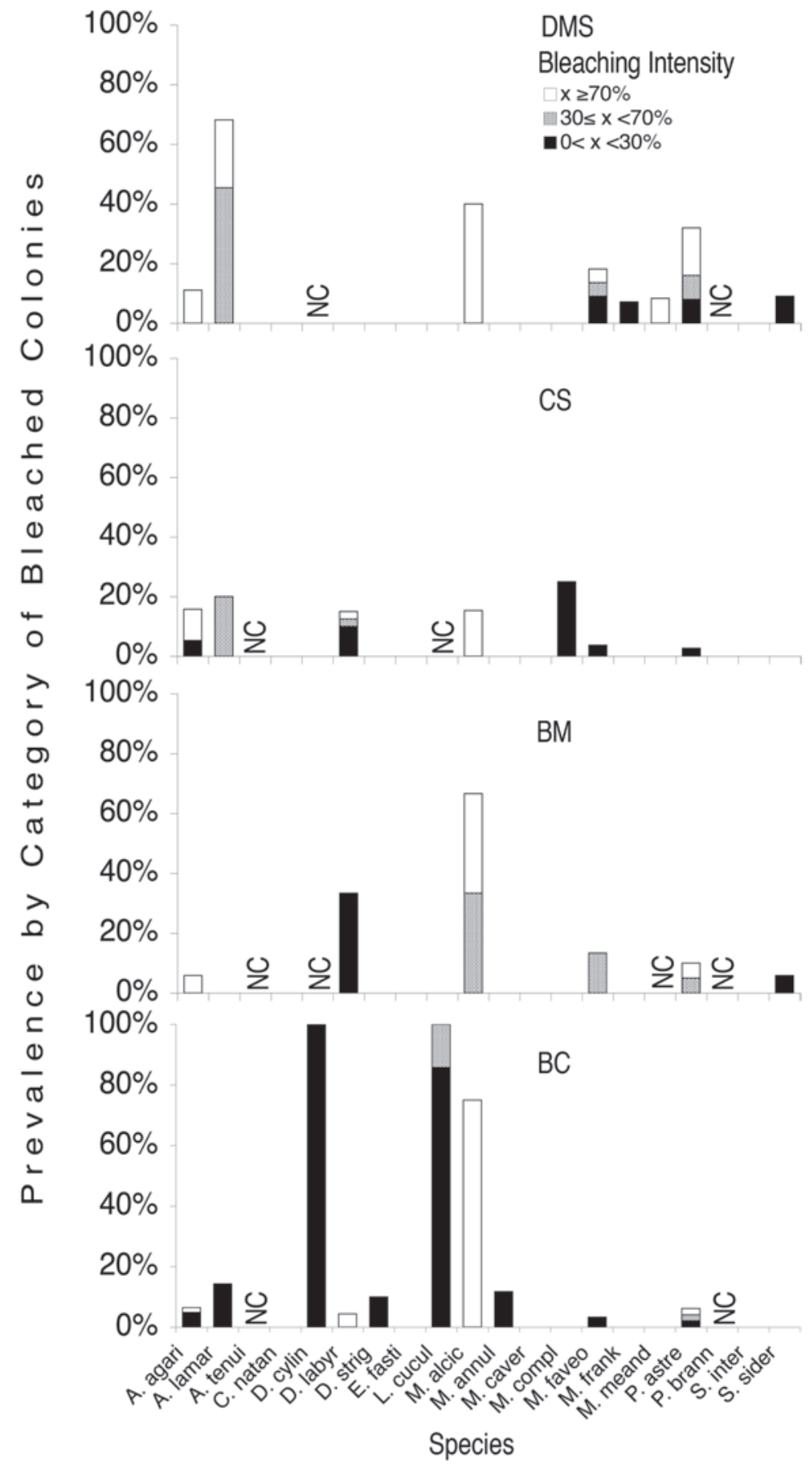

Fig. 5. Prevalence of bleaching by species for the three bleach categories $(0<\mathrm{X}<30 \%, 30-70 \%,>70 \%$.) at the period of maximum extent of bleaching. The total of colonies are are indicated in Table 3. 
bleaching event were found: pre-bleaching phase: August; initial bleaching phase: October; bleaching peak: November; and post-bleaching phase: March.

The temporal evolution of bleaching is related to the progressive increase of the water temperature, from August to mid-October. However, the maximum bleaching was registered in November. This is not a surprising result, because if we sustain the hypothesis that the excessive increase in water temperature (above the maximum monthly average) is one of the main factors that generate bleaching, then reef waters subject to longer periods of excessive temperatures will have more intense bleaching. Thus, colonies subject to high water temperatures for longer periods (high DHW) will show a maximum bleaching out of phase with the peak of the maximum water temperature. This interpretation agrees with Gleason and Strong (1995) who suggest that bleaching is a function of cumulative heat stress.

Contrary to this homogeneous temporal pattern of bleaching prevalence, the spatial pattern of bleaching intensity showed a high variability in the archipelago, as indicated by the statistically significant differences (TwoFactor ANOVA), between the averages of pale or bleached coral surface, among the coral communities of this study.

Another indicator of spatial variability in bleaching was the evident difference observed in the proportion of the total number of partially or totally pale or bleached colonies, for the different coral communities that were monitored. Both the analysis of affected coral tissue cover and the total proportion of pale or bleached colonies indicate that Boca de Cote and Dos Mosquises Sur reefs were the most affected by the bleaching event of 2005. However, bleaching was low, with an average number of affected colonies under $10 \%$ and an average bleached coral surface per colony under $8 \%$.

Two of the coral communities that were more affected by bleaching had very high density of corals per area unit (Boca Cote: 76.25 $\mathrm{col} / 40 \mathrm{~m}^{2}$, Dos Mosquises Sur: $75.66 \mathrm{col} / 40$ $\mathrm{m}^{2}$ ). This result is not a consequence of the differences of the sampled area in the different reefs, because the calculations of the proportion of affected colonies by bleaching were standardized in relation to the total number of colonies observed in each site. Several factors could be responsible for these spatial differences observed in the bleaching at Los Roques, among them physical factors such as very high temperatures exceeding the local average temperature, excessive radiation, a variation in the sedimentation and re-suspension of sediments in the water column; or biological factors such as the dominant coral species (in terms of abundance) at each site and their greater or lesser degree of sensitivity to bleaching, among others. The physical factors mentioned are closely related to the water circulation patterns that are characteristic at each reef site. In this study, two of these factors were considered: the water temperature and the dominant species of the coral communities studied.

The temperature data registered in the reef sites indicate a similar temporal pattern of temperature changes for the different sites evaluated, except for Laguna Central (Fig. 2). According to this, it is not possible to relate the observed differences in the prevalence and intensity of coral bleaching with differences in temperature between sites where temperature records were taken (BM, CS and DMS). We do not have the continuous record of the temperature at $\mathrm{BC}, \mathrm{DMH}$ and $\mathrm{CA}$ (sensors were not in place). However, the $\mathrm{BC}$ site is very close to Sebastopol (Fig. 1), and therefore temperatures may be similar. We consider that the coral communities studied at DMH and CA are under physical conditions slightly different from the four previously mentioned, particularly because of the shallower average depth. Additionally, because of their shallower depth and location in the archipelago, both are subject to constant currents (unpublished observations). Also, it was only at these two sites where we observed live colonies of A. cervicornis and A. palmata, and they were dominant components of the coral species composition. The dominance of these species under such environmental conditions is widely documented in the literature. 
Probably such hydrodinamic conditions ameliorate the increase of seawater temperature, and their stressing effect on corals (Nakamura \& Woesik 2001).

\section{Los Roques bleaching and other areas of the Caribbean}

Compared to other Caribbean reefs, we consider that the bleaching intensity was low in 2005, and had low impacts on corals in Los Roques. According to data published by NOAA (http://coralreefwatch.noaa.gov/caribbean2005), estimates of coral cover bleaching were $90 \%$ in the British Virgin Islands, $80 \%$ in the U.S. Virgin Islands, 60\% in Trinidad and Tobago, $52 \%$ in the French West Indies, and $85 \%$ in the Netherlands Antilles. Delgado (2006) reported temperatures over $31.8^{\circ} \mathrm{C}$ for more than 14 weeks in the shallow reef areas of Cayo Largo, Fajardo, in Puerto Rico, resulting in a massive mortality of corals in this area (data available in http://amp-pr.org/ciel). According to NOAA this temperature exceeded the maximum limits of monthly SST registered for Puerto Rico $\left(28.5^{\circ} \mathrm{C}\right)$. In comparison, annual subsurface temperature averages recently registered at Los Roques (2005-2006) were of $27.5^{\circ} \mathrm{C}\left(\mathrm{sd}=1.09^{\circ} \mathrm{C}\right)$ and the highest temperature registered in Los Roques during this bleaching year was $30^{\circ} \mathrm{C}$; this temperature remained in most study areas for 5.5 weeks except in the shallower patch reefs of the "Laguna Central" site, where it remained for 11.8 weeks. In both cases (Puerto Rico and Los Roques) the increase of water temperature was around $3^{\circ} \mathrm{C}$; however, the DHW was much longer in Puerto Rico. Additionally, In the middle of August temperature dropped at deep reefs in Los Roques, decreasing the temperature at these sites for a week (Fig. 2). The differences between these regions could be partially related to the period that warm waters influenced coral reefs in these studies (the DHWs), rather than to differences in the maximum registered temperature. Another important factor to be considered is the bleaching history of each site, since the capacity of corals to adapt to elevated temperatures have been suggested in the litterature (Buddemeir \& Fautin 1993, Done 1999, Glynn 1993). Unfortunately, there is only limited information about possible bleaching events in Los Roques (Losada 1988, Villamizar 2003), and the frequency, intensity, and spatial distribution of these events are unknown.

As with previous bleaching events, the 2005 bleaching event was of low severity and intensity. Lang et al. (1992) registered for a 1987 bleaching event $13.5 \%$ pale, $4.1 \%$ bleached and 2.6\% dead corals; Villamizar et al. (2003) reported for 1999 (not a global bleaching year), $<4 \%$ of pale or partially bleached coral colonies and none totally bleached, in 13 coral reefs evaluated at Los Roques. Moreover, during the bleaching event of 1987 Losada (1988) did not find any evidence of bleaching in Los Roques. However, Wolfgang (1995) reported a moderate to severe bleaching event throughout the western Caribbean from Venezuela to the Flower Garden Banks off Texas, where temperature exceeded $30^{\circ} \mathrm{C}$. This medium intensity event was observed in October, in the back reef zone of a fringing reef (Playa Mero) of Morrocoy National Park (northwest coast of Venezuela). At this site, the average of SST at $0.8 \mathrm{~m}$ of depth was of $32^{\circ} \mathrm{C}$. At this depth, most colonies of the zoanthid Palythoa caribaeorum, M. alcicornis, M. complanata, C. natans, $P$. porites, $P$. astreoides, and the octocoral Briareum asbestinum were completely bleached (Villamizar unpubl. data).

Another factor that has been related to bleaching differences between coral communities is the level of anthropogenic impacts. Nagelkerken (2006) found a higher percentage of coral showing bleaching-related tissue mortality at impacted reef sites than at the control sites (non-impacted) for the total number of corals and for corals with $<50 \%$ of their surface area bleached. The reef sites selected at Los Roques are not under a high anthropogenic pressure, and are subject to approximately similar ecological conditions, so there is a low probability that some of the bleaching differences found between them can be attributed to this factor. However, this interpretation is not 
conclusive, because this factor was not evaluated in this study.

\section{Coral species and bleaching}

According to Marshall and Baird (2000) and Kayanne et al. (2002), massive or mounding corals such as poritids and faviids are less susceptible to the effects of bleaching than branching corals such as acroporids and pocilloporids. In general, the coral communities studied were dominated mainly by species of Faviidae and Poriitidae. Most of the Acroporid species, especially, A. palmata, are very scarce in the archipelago. They have been intensively affected by the white band disease since the 1980s, decreasing their populations to very low levels (García et al. 2003, Villamizar 2003). This could explain, in part, the general lower impact of bleaching in Los Roques, however, this theory can not explain the differences of bleaching between Los Roques in comparison with other areas of the Caribbean, since most of the Caribbean reefs do not have Acroporid colonies in their communities. Therefore, the hypothesis of Marshall and Baird (2000) and Kayanne et al. (2002) cannot be used to explain the low intensity of bleaching in Los Roques, nor the differences of bleaching between Los Roques and other reefs of the Caribbean Region.

The results of this study suggest that, of the species present in Los Roques, the ones with a highest susceptibilty to bleaching (more colonies with partial bleaching) were the following (in hierarchical order): D. labyrinthiformis, M. annularis, M. complanata, A. lamarcki, $L$. cucullata, M. alcicornis, M. faveolata, and $P$. astreoides. According to the Chi Square Test to evaluate the bleaching intensity (in terms of the affected area of the colony) between the different coral species, $P$. astreoides, $C$. natans and $M$. faveolata were found to be the species tending to have a larger affected area $(>70 \%)$. This result could be interpreted in terms of a higher relative sensitivity of these species to bleaching. Thus, in both Boca de Cote as in Dos Mosquises Sur, two of these three species form part of the dominant species group. Therefore there is a possibility that the dominance of these more sensitive species to bleaching may partially explain a higher prevalence and intensity of bleaching in these reefs in comparison with the rest reef sites. Finally, we consider that the fact that the colonies of a particular species bleach totally during a particular bleaching event, does not necessarily imply that the colony will die. In this study, bleaching recovery was almost total by mid-March 2006. A possible explanation is that most colonies only paled and very few bleached completely. This condition may allow a higher rate of recovery of the zooxanthellae in the coral tissue, as there can be repopulation by remnant zooxanthellae. Another more elaborated argument is the one suggested by Rowan (2004), whereby some corals might be able to combat thermal stress by associating with heat-tolerant Symbiodinium spp. clades. In this sense the Adaptive Bleaching Hypothesis (Buddemeier \& Fautin 1993), states that frequent and severe environmental stresses tend to favor stress-resistant coral-zooxanthellae associations. To date, there are no studies about the Symbiodinium coral species of Los Roques, so there is no information to this respect.

This study is the first formal attempt to monitor bleaching events in Los Roques; we expect that the knowledge gained for this important reef system of the Southern Caribbean will contribute to comparisons with other areas of the Wider Caribbean. We also hope to gain a better understanding of the sensitivity and recovery of the corals from bleaching. We suggest that the monitoring of bleaching events must be done regularly each year, to gain practical information on how bleaching acts as a structuring force in ecological communities.

\section{ACKNOWLEDGMENTS}

This project was financed by Conservation International and Fundación Científica Los Roques. Special thanks to all the field volunteers that helped to collect the data: BIOSUB Diving Club, from the Sciences Faculty of the 
Universidad Central de Venezuela, to Samuel Narciso from FUDENA, Carlos Del Mónaco, Mario Yallonardo, and to Roberto Pépolas, Angel Chiriboga and Mariana Vera from the Charles Darwin Foundation. We thank three anonymous reviewers for providing helpful comments. This paper is the Scientific Contribution Number 51 of Fundación Científica Los Roques.

\section{RESUMEN}

Evaluamos el blanqueamiento de algunos arrecifes del Parque Nacional Archipiélago de Los Roques en Venezuela en 2005. En cada arrecife delimitamos 2-6 áreas de $40 \mathrm{~m}^{2}$ (5-9 y 12-17 m), en las cuales evaluamos la condición de todas las colonias coralinas, categorizándolas en normales, pálidas o blanqueadas. Establecimos tres subcategorías de palidez o blanqueamiento: $0<\mathrm{X}<30 \%, 30-70 \mathrm{y} \geq 70 \%$. Muestreamos en agosto, octubre y noviembre de 2005 y en marzo 2006. Las mayores temperaturas sub-superficiales del agua en los arrecifes se registraron los días 7 y 8 de octubre, con un máximo de $30^{\circ} \mathrm{C}$. El blanqueamiento fue de intensidad leve y fue evidente en la primera semana de noviembre, extendiéndose tanto a zonas someras como profundas de los arrecifes. La intensidad del blanqueamiento presentó diferencias entre arrecifes. pero no entre profundidades (ANDEVA de dos factores. $\mathrm{p}<0.05$ ). Del total de colonias monitoreadas (1660) una proporción muy pequeña se blanqueó totalmente (0.80\%), un número mayor se blanqueó parcialmente (6.3\%) y la mayoría estaban parcialmente pálidas $(20.9 \%)$. No todas las especies de los arrecifes se blanquearon al mismo tiempo. Palythoa caribaeorum, Millepora alcicornis, Millepora complanata, Diploria labyrinthiformis y Montastraea faveolata fueron las primeras especies en afectarse. La recuperación del blanqueamiento fue casi total a finales de marzo. Comparado con otros arrecifes del Caribe, el blanqueamiento en Los Roques fue mucho menos severo; sin embargo, a mediano y largo plazo, en una escala de tiempo ecológico, los efectos del blanqueamiento sobre Los Roques dependerán, entre otros, de la frecuencia, intensidad y permanencia de las aguas sobrecalentadas en el sistema.

\section{REFERENCES}

Buddemeier, R.W. \& D.G. Fautin. 1993. Coral bleaching as an adaptive mechanism: a testable hypothesis. BioScience 43: 320-326.

Brown, B.E. 1987. Worlwide death of corals - natural cyclical events or man-made pollution? Mar. Poll. Bull. 18: 9-13 .
Clausen, C. \& A.A. Roth. 1975. Effect on temperature adaptation on calcification rate in the hermatypic coral Pocillopora damicornis. Mar. Biol. 33: 93-100.

Coles, S.L. \& B.E. Brown. 2003. Coral Bleaching-Capacity for Acclimatization and Adaptation. Adv. Mar. Biol. 46: 183-215.

Done, T.J. 1999. Coral community adaptability to environmental change at the scales of regions, reefs and reef zones. Amer. Zool. 39: 66-79.

Donner, S.D., T.R. Knutson \& M. Oppenheimer. 2007. Model-based assessment of the role of human-induced climate change in the 2005 Caribbean coral bleaching event. Proc. Nat. Acad. Sci. 104: 5483-5488.

García, A., A. Cróquer \& S.M. Pauls. 2003. Estado actual de las enfermedades y otros signos de deterioro coralino en siete arrecifes del Parque Nacional Archipiélago de Los Roques, Venezuela. Rev. Biol. Trop. 51 (Supl. 4): 173-180.

Gleason, M.W. \& A.E. Strong. 1995. Applying MCSST to coral reef bleaching. Adv. Space Res. 16: 151-154.

Glynn, P.W. 1984. Widespread coral mortality and the 1982-1983 El Niño warming event. Environm. Conserv. 11:133-146.

Glynn, P.W. 1993. Coral reef bleaching ecological perspectives. Coral Reefs 12: 1-17.

Glynn, P.W. 1996. Coral reef bleaching: facts, hypothesis and implications. Global Change Biol. 2: 495-509.

Glynn, P.W. 2000. El Niño-Southern Oscillation mass mortalities of reef corals: a model of high temperature marine extinctions? In: E. Insalaco, P. Skelton and T Palmer (eds.), Organism-Environment Feedbacks in Carbonate Platforms Systems: components and interactions. Geological Society, London, Special Pub. 178: 117-133.

Goreau, T.P. 1964. Mass expulsion of zooxanthellae from Jamaican reef communities after Hurricane Flora. Science 145: 383-386.

Guzmán, H.M. \& J. Cortés 1992. Cocos Island (Pacific of Costa Rica) coral reefs alter the 1982-1983 El Niño disturbance. Rev. Biol. Trop. 40: 309-324.

Hoegh-Guldberg, O. 1999. Climate change, coral bleaching and the future of the world's coral reefs. Mar. Freshwater Res. 50: 839-866.

Kayanne, H., S. Harii, Y. Ide \& F. Akimoto. 2002. Recovery of coral populations after the 1998 bleaching on Shiraho Reef, in the southern Tyukyus, NW Pacific. Mar. Ecol. Prog. Ser. 239: 93-103. 
Kramer, P. 2003. Synthesis of coral reef health indicators for the western Atlantic: results of the AGRRA program (1997-2000). In: J.C. Lang (ed.) Status of Coral Reefs in the Western Atlantic: Results of initial Surveys, Atlantic and Gulf Rapid Reef Assessment (AGRRA) Program. Atoll Res. Bull. 496: 1-55.

Lang, J., H.R. Lasker, E.H. Gladfelter, P. Hallock, W.C. Jaap, F.J. Losada \& R.G. Muller. 1992. Spatial and temporal variability during periods of "recovery" after mass bleaching on Western Atlantic coral reefs. Amer. Zool. 32: 696-706.

Lesser, M.P., W.R. Stochaj, D.W. Tapleyl \& J.M. Shick. 1990. Bleaching in coral reef anthozoans: effects of irradiance, ultraviolet radiation, and temperature on the activities of protective enzymes against active oxygen. Coral Reefs 16: 187-192.

Losada, F.J. 1988. Report on coelenterate bleaching in the southern Caribbean, Venezuela. In J.C. Ogden and R.I. Wicklund (eds). Mass Bleaching of Coral Reefs in the Caribbean: A Research Strategy. Nat. Undersea Res. Prog. Res. Rep. 88: 38-41.

Marshall, P.A. \& A.H. Baird. 2000. Bleaching of corals on the Great Barrier Reef: differential susceptibilities among taxa. Coral Reefs 19: 155-163.

Meesters, E.H. \& R.P.M. Bak. 1993. Effects of coral bleaching on tissue regeneration potential and colony survival. Mar. Ecol. Prog. Ser. 96: 189-198.

Nagelkerken, I. 2006. Relationship between antrhropogenic impacts and bleaching-associated tissue mortality of corals in Curacao (Netherlands Antilles). Rev. Biol. Trop. 54 (Suppl. 3): 31-43.

Nakamura, T. \& R. van Woesik. 2001. Water-flow rates and passive difusión partially explain differential survival of corals during the 1998 bleaching event. Mar. Ecol. Prog. Ser. 212: 301-304.

Podestá, G.P. \& P. Glynn. 2001. The 1997-98 El Niño Event in Panamá and Galápagos: an update of thermal stress indices relative to coral bleaching. Bull. Mar. Sci. 69: 43-59.

Rodríguez, B. 2001. Paisaje y ambiente físico, p. 77-84 In: J. Zamarro (ed.). Guía del Parque Nacional Archipiélago de Los Roques. Ecograph, Caracas, Venezuela.
Rowan, R. 2004. Thermal adaptation in reef coral symbionts. Nature 430: 742.

Villamizar, E., J.M. Posada \& S. Gómez. 2003. Rapid assessment of coral reefs in the Archipiélago de Los Roques National Park, Venezuela (Part I: stony corals and algae). In: J.C. Lang (ed.). Status of Coral Reefs in the Western Atlantic: Results of Initial Surveys, Atlantic and Gulf Rapid Reef Assessment. Atoll Res. Bull. 496: 512-529.

Weil, E. 2003. The corals and coral reef of Venezuela, p. 303-330. In: J. Cortes (ed.) Latin American Coral Reefs. Elsevier, Amsterdam, Netherland.

Williams, E.H. \& L. Bunkley-Williams 1990. The worldwide coral reef bleaching cycle and related sources of coral mortality. Atoll Res. Bull. 335: 1-71.

Winter, A., R.S. Appeldoorn, A. Bruckner, E.H. Williams Jr. \& C. Goenaga. 1998. Sea surface temperatures and coral reef bleaching off La Parguera, Puerto Rico (northeastern Caribbean Sea). Coral Reefs 17: 377-382.

Wolfgang, L. 1995. Reef bleaching spreads in the Caribbean. Science 270: 919.

Zar, J.H. 1999. Biostatistical Analysis. Prentice, New Jersey, USA. 663 p.

\section{INTERNET REFERENCES}

Delgado H., G. 2006. Acelerada destrucción de arrecifes. Downloaded: 8 November 2006. http://amp-pr.org/ ciel..

NOAA. 2005. Caribbean Basin Bleaching Event. Downloaded: 10 april 2007). http://coralreefwatch. noaa.gov/caribbean2005

REEFCHECK. Coral Reef Impacts of the 2005 Caribbean Bleaching Event. Downloaded: 30 September 2007. www.reefcheck.org/PDFs/Caribbean_Bleaching_ Report.pdf 